\title{
PRIVATE LAW SCHOOLS IN INDONESIA: THEIR DEVELOPMENT, GOVERNANCE AND ROLE IN SOCIETY
}

\author{
V. Selvie Sinaga* \\ Atma Jaya Catholic University of Indonesia, J1. Sudirman Kav. 51, \\ Jakarta 12930, Indonesia \\ e-mail: valerie.selvie@atmajaya.ac.id
}

Published online: 15 July 2018

To cite this article: Sinaga, V. S. 2018. Private law schools in Indonesia: Their development, governance and role in society. International Journal of Asia Pacific Studies 14 (2): 165-185, https://doi.org/10.21315/ijaps2018.14.2.8

To link to this article: https://doi.org/10.21315/ijaps2018.14.2.8

\begin{abstract}
Legal education in Indonesia was introduced in the Dutch colonial period. During the early years of Indonesia's independence, legal education was mostly offered by public universities, and all public law schools were funded entirely by the government of Indonesia. Consequently, the views and policies of these law schools mostly paralleled the government of Indonesia's policies and views. Later, private institutions participated in providing legal education to Indonesian people interested in studying law. Although private law schools played an important role as an alternative for people who could not enter public law schools for many reasons (e.g., age limit, racial and religious discrimination fears, and political views), they received discriminatory treatment from the government before the 1990s. Prior to the reform era, which began in 1998, the participation of these law schools in the public sector was limited. Only a few alumni from these schools were chosen to hold significant positions in the public sector. After 1998, the situation changed, and the role of private law schools has become more significant in the country. This paper will document the changes that have been made over time by private law schools in an attempt to attain prominence in Indonesia. Additionally, this paper analyses the role of Indonesian private law schools in society, especially after the reform era started in 1998.
\end{abstract}

Keywords: Private law school, Indonesia, Indonesian education, legal education, discrimination studies 


\section{INTRODUCTION}

Legal education in Indonesia is provided by both public and private institutions. In terms of quantity, private institutions that provide legal education are more abundant than their public counterparts. However, the private institutions are less preferred because of the stigma in society that assumes that all public institutions are far better than the private ones. People believe that private law schools generally provide a lower quality education.

This stigma emerged from the fact that prior to the 2000s, all public universities were financed entirely by the government, meaning that the tuition fees could be held at a minimum. ${ }^{1}$ In addition, the government fully supported the development of public universities, ${ }^{2}$ making it easier for public institutions to grow, compared to private institutions. However, if given the same support and opportunities, private law schools have the same potential to become as good as their public counterparts.

Therefore, the role of private institutions in providing legal education in Indonesia should not be underestimated. Private law schools have accommodated students who wished to be lawyers but were not able to study in public institutions due to limited capacity and/or because they were hindered by the age limitation rule for those enrolling. Moreover, since the public institutions were financed and supported by the government, the policies and views of the public institutions were more likely to follow those of the government. The private law schools became an alternative for those people who had been unable to enter public law schools because of the Indonesian government's policies. In addition, to date, Indonesian private law schools have made a great deal of progress in improving their quality.

However, despite the progress that private law schools have made, they are still not given their due by the Indonesian legal academy and by the legal profession. This paper will document the changes that have been made by private law schools over time in the service of attaining prominence in Indonesia. In addition to that, this paper also analyses the role of Indonesian private law schools in society, especially after the reform era started in 1998.

\section{THE DEVELOPMENT OF LEGAL EDUCATION IN INDONESIA}

Legal education has existed in Indonesia since the Dutch colonial period. At first, legal education was provided at the secondary level by the establishment of the Rechtschool in 1908. Sixteen years later, legal education was elevated to the tertiary level by the establishment of the Rechthogeschool or Faculteit der 
Rechtsgeleerdheid of Batavia (Juwana 2006). When the Pacific War began in 1941, the Dutch colonial government stopped teaching and learning activities in the Rechthogeschool, but they re-opened it again later in 1947 as the Nood Universiteit van Indonesie, currently known as the University of Indonesia (UI). ${ }^{3}$ After that, another law school was opened in 1949 in Yogyakarta, known currently as the Faculty of Law of Gadjah Mada University (UGM). ${ }^{4}$

In the early years of Indonesian independence, more and more law schools were established, most of which were public universities. Examples of these were the faculties of Law at Airlangga University (Unair) (1954) in Surabaya, the University of North Sumatra (USU) (1954) in Medan, Pattimura University (Unpati) (1956) in Ambon, Hasanuddin University (Unhas) (1956) in Makassar, Padjajaran University (Unpad) (1957) in Bandung, Diponegoro University (Undip) (1957) in Semarang, and Sriwijaya University (Unsri) (1957) in Palembang. ${ }^{5}$

In addition to public universities, private institutions also participated in providing legal education in Indonesia. In the early years of Indonesian independence, two private law faculties were founded, at the Islamic University of Indonesia (1948) ${ }^{6}$ and Krisnadwipayana University (1952). ${ }^{7}$ In the following years, the number of law programmes in Indonesia continued to grow. Currently, there are a total of 393 law programmes throughout Indonesia, and as many as 346 are managed by private institutions. ${ }^{8}$

The Rechtshogeschool was established by Hooger OnderwijsOrdonnantie (Gazettes No. 456 and 457 of 1924), which stipulated that 24 courses would be taught in the Rechtshogeschool. These courses include Introduction to Legal Studies, Constitutional and Administrative Law, Civil Law and Civil Procedural Law, Criminal Law and Criminal Procedural Law, Customary Law, Islamic Law, Trade Law, Sociology, Public Administration, Dutch East Indies Nations Science, Malay, Javanese, English, Latin and Philosophy of Law. With the permission of the Governor-General, those 24 subjects were allowed to be developed to accommodate social changes and developments in the community. ${ }^{9}$

The course of study at the Rechtshogeschool, which was divided into two stages, took five years to complete. The first stage took two years and ended with the completion of a candidate examination (candidaats-examen), while the second stage was completed by taking a doctoral examination (doctoraal-examen). In the last year, which was also known as the third part of the doctoral examination, students were given course options of Civil Law, Criminal Law, Constitutional Law and Economy-Sociology. Those who completed the test were entitled to use the title of Meester in de Rechten. This 
title gave the right to that particular person to become an advocate or lawyer or take other judicial-related positions. Aside from that, the title could also be used as an avenue for employment in the civil service or public education. ${ }^{10}$

During the Dutch colonial period, the mission of higher education in law was to produce people with legal expertise who were able to fill the positions of judges in the landraad (indigenous court) ${ }^{11}$ and colonial government officials. ${ }^{12}$ The Rechtschogeschool taught a closed legalistic system that did not relate well to the social reality in the field. ${ }^{13}$ This kind of teaching method was considered suitable to produce law clerks in a bureaucracy.

During the first three decades after Indonesian independence, the original curriculum and teaching methods based on the Dutch model were still being practised. There were differences, though; for example, the teaching materials were in Indonesian instead of in Dutch, the latest Supreme Court jurisprudence was not used as the sole reference to explain a particular legal principle or interpretation, and students learned by rote memorisation using simple college textbooks. These were considered to be the reasons for the decline in the quality of graduates of higher legal education within that period, compared with the graduates of the Rechtshogeschool during the Dutch colonial period.

Although the teaching method was still similar to the method used in the colonial period, the mission of legal education had already changed. In the Old Order era, the mission was to produce legal scholars who dared to change the colonial-inherited law and had the expertise to revolutionise the laws of Indonesia, whose status had changed from that of a colony to that of an independent country. ${ }^{14}$ When the power shifted to the New Order, legal education was designed to produce legal scholars capable of supporting the development of Indonesia, particularly in the area of economic law. ${ }^{15}$

In the middle of the New Order era, Dutch colonial teaching methods were no longer deemed suitable for the teaching of law in Indonesia. Professor Mochtar Kusumaatmadja, who was the Chairman of the Consortium of Legal Studies (Konsorsium Ilmu Hukum or KIH) ${ }^{16}$ and the Minister of Justice during that era, advocated the idea of modernising the teaching of law in Indonesia by emphasising the importance of sociological approaches to every element of Indonesian legal education. ${ }^{17}$ In addition to that, he also criticised the unpreparedness of law graduates from a practical perspective. ${ }^{18}$ The response to the criticisms was a change to Indonesian law school curriculum in 1993. The 1993 curriculum was designed so that the law graduates needed not only to understand legal theories but also to be proficient in legal practices. ${ }^{19}$ 
However, the implementation of that 1993 curriculum, which was renewed in 2000, has not been optimal and consistent. The substance of the teaching materials on the subject of practical legal training was not consistent between universities. In terms of facilities, not every school of law had a legal clinic for legal practicums. Aside from that, subjects in the curriculum offered by law faculties in Indonesia were too disparate and considered to be in need of evaluation of their academic validity. ${ }^{20}$

Since 2003, the government no longer emphasises the importance of uniformity in the implementation of national curricula in Indonesian higher education, including in law programmes. Law No. 20 of 2003 on the National Education System ${ }^{21}$ states that higher education curricula shall be developed by each higher education institution concerned, taking into consideration national standards of education for each particular study programme. ${ }^{22}$ Moreover, the most recent legislation governing higher education in Indonesia, Law No. 12 of 2012 on Higher Education, also re-emphasises this policy. It becomes the responsibility of each university to conduct the development of their curriculum in accordance with the national education standards of Indonesia. Although the responsibility for this has been given to universities, the law states that every higher education curriculum must include subjects in religion, Pancasila, ${ }^{23}$ civics and Indonesian language. ${ }^{24}$

Currently, legal education in Indonesia, similar to education in other subjects, has been required to adjust its curriculum so that it is in line with the Indonesian National Qualifications Framework (Kerangka Kualifikasi Nasional Indonesia or KKNI) ${ }^{25} \mathrm{KKNI}$ was formed in order to prepare human resources in Indonesia to welcome the Association of Southeast Asian Nations (ASEAN) Economic Community (AEC) in early 2016. The previous curriculum in Indonesia was constructed based on the achievement of competencies, while the KKNI curriculum must be based on learning outcomes in accordance with the levels of qualifications in the KKNI. ${ }^{26}$

In conclusion, the changes to Indonesian legal education have been influenced by politics and regime policies in utilising law to reach their goals. In the colonial era, the goal of the colonial government in introducing legal education to Indonesia was merely to rectify the lack of human resources needed to fill posts of the native courts, landraad and low level colonial government officials. In the Old Order era (1945-1965), President Soekarno redirected legal education in Indonesia to meet the demands of the revolution. He insisted that law graduates must have the capacity to update laws that had been inherited from the Dutch colonial government. After that era, legal education had different goals to support the economic development that was 
heavily emphasised by the New Order (1966-1998) regime. ${ }^{27}$ From these past policies, Indonesian law schools and scholars have learned many approaches to offer a better legal education today. Since the reform era started in 1998, the government has reduced its involvement in governing legal education in Indonesia. The government now allows law schools to form their own curriculum that will be able to produce law graduates who have the capacity to compete at the ASEAN level.

\section{THE GOVERNANCE OF PRIVATE HIGHER EDUCATION INSTITUTIONS IN INDONESIA}

The discussion of legal education in Indonesian private higher education institutions cannot be separated from the general situation of Indonesian private university governance, as there is no current regulation intended specifically for law programmes. This section explains the past and present governance of private higher education institutions. This section is intended to help readers understand the context of Indonesian private university governance in order to comprehend the whole topic of this paper.

An emergent academic literature discusses private institutions of higher education around the world. ${ }^{28}$ Higher education in major Asian countries, including Indonesia, has been dominated by private institutions. Even in Japan, South Korea, Taiwan and the Philippines, the enrolment of students in private higher education institutions has been reported to be approximately 80 percent. ${ }^{29}$ However, unlike private universities in the United States (US), ${ }^{30}$ only a few private universities in the Asian region are considered to be of high quality. ${ }^{31}$ In terms of governance and funding, private universities in most Asian countries are highly regulated by the government, although they only receive limited public funding. ${ }^{32}$ This situation is not unique to Indonesia. Following this pattern, the higher education sector in Indonesia is dominated by private institutions, yet they are considered as lower quality compared with the equivalent public institutions. Similar to private universities in most Asian countries, Indonesian private higher education institutions are over-regulated and receive little financial support from the government.

Organisationally, higher education in Indonesia has been the responsibility of the Directorate General of Higher Education of the Ministry of Research, Technology and Higher Education ${ }^{33}$ since President Joko Widodo announced his new cabinet on 26 October $2014 .{ }^{34}$ Prior to that, the government agency responsible for higher education affairs was the Ministry of Education 
and Culture. With respect to private universities, the Indonesian government established a working unit named the Coordinator of Private Universities (Kopertis) under the Directorate General of Higher Education, Ministry of Research, Technology and Higher Education to conduct training and to supervise private universities within each Kopertis' working area. ${ }^{35}$ Currently, there are 12 Kopertis $^{36}$ covering the entire territory of Indonesia.

Since the private sector began to participate in the provision of higher education in various disciplines, including legal education, the Indonesian government has issued a series of regulations and systems to create order and to maintain control in the management of private universities. Some of the regulations are discriminatory against private universities. One of these regulations was Government Regulation No. 23 of 1959 on the Rules of the State Examination to Obtain a University Degree for Private University Students. This regulation requires private university students to complete a longer process by taking the state exam in advance of obtaining their bachelor's degree. ${ }^{37}$

Furthermore, the country issued Law No. 22 of 1961 on Higher Education. Similar to Government Regulation No. 23 of 1959, the law continued to maintain a discriminatory policy against private universities. Since it was assumed that private universities were not yet capable of being independent, the law classifies private universities into three categories, namely, "Registered," "Recognised" and "Equated." 38 Registered status was given to private universities that had registered themselves with the Minister of Education by submitting a notarial deed of establishment of the university. Statutes, properties and/or sources of income of the university, curriculum plans, and a list of faculty members, including the education and employment history of each staff member and subjects taught, had to be submitted within six months of the date of establishment. ${ }^{39}$ Private universities with Registered status were not allowed to conduct examinations independently. However, private universities with Recognised status were allowed to conduct examinations under the instruction and supervision of the Minister and could issue diplomas of the same value as those from the public universities. ${ }^{40}$ Private universities with Equated status had the right to conduct examinations independently with the same credibility as the public universities' examination and promotion processes. ${ }^{41}$ Hierarchically, Registered private universities could be upgraded to Recognised and the Recognised private universities could become Equated by the decision of the minister upon proposal by the Private Higher Education Agency (Lembaga Perguruan Tinggi Swasta or LPTS). ${ }^{42}$ 
The LPTS was a body formed by the Indonesian government under Law No. 22 of 1961 to foster and supervise private universities. ${ }^{43}$ The authority of the LPTS included, but was not limited to:

1. Proposing the elevation of private universities' statuses; ${ }^{44}$

2. Reporting and proposing the closure of private universities that violated the state's Constitution or policies or did not possess the material, personnel or spiritual capacity to conduct teaching of higher education; ${ }^{45}$

3. Giving considered opinions to the Minister regarding the merger of two or more private universities. ${ }^{46}$

Even though the creation of the LPTS had been mandated by Law No. 22 of 1961, the implementation of the law could only be achieved several years later. The Minister of Culture Decree No. 1/PK/1968 dated 17 February 1968, created seven LPTSs under the name of University Coordinator (Koordinator Perguruan Tinggi or Koperti). The nomenclature Koperti was then changed to Kopertis by Decree No. 079/O/1975 dated April 17, 1975. ${ }^{47}$ Kopertis, which was originally divided into seven regions, then expanded into nine regions in 1982 and finally to 12 regions $^{48}$ in $1990 .{ }^{49}$

After Law No. 22 of 1961 on Higher Education, there were many legal instruments issued by the Indonesian government to strictly regulate private universities, such as Government Regulation No. 15 of 1965 on the Establishment of Private Universities, which tightened rules on the establishment of private universities in Indonesia. Written permission needed to be obtained from the Minister of Higher Education and Science if private parties wanted to establish a university. Prior to this, private parties had been able to conduct activities in the established university and then report to government within three months of its establishment. ${ }^{50}$

During the New Order era (1965-1998), when economic development was primary, education functioned as a support for successful economic development. This greatly influenced education in Indonesia, particularly higher education. Student enrolment in higher education peaked in Indonesia between 1970 and 1980. In response to the demands of higher education, private parties started to establish many universities during this period. ${ }^{51}$ Unfortunately, most of the private universities established only catered to the immediate higher education needs of the community, so they did not have much financial capacity, human resources, or adequate facilities. ${ }^{52}$ As a consequence of the lack of resources, private universities tended to set up social science and 
humanities programs ${ }^{53}$ including law, which do not require many practical facilities compared with science programmes such as engineering or medicine.

It could not be denied that a private university established without adequate financial capacity, human resources and facilities would not be able to organise a high-quality education. These concerns led to the tight controls ${ }^{54}$ retained by the Indonesian government for higher education conducted by the private sector. ${ }^{55}$

However, in the 1980s and 1990s, the Indonesian government had begun to pay attention to private universities. To support private universities that were less sound financially, the government issued Government Regulation No. 39 of 1982 on Private University Assistance. ${ }^{56}$ The government also issued Government Regulation No. 30 of 1990 on Higher Education, which harmonised the process for the establishment of state and private universities..$^{57}$ In terms of supervision, this government regulation did not distinguish between state and private universities. ${ }^{58}$ The most important attention from the government to private universities in Indonesia was the removal of the stepped statuses of private universities as stated in Government Regulation No. 60 of 1999 on Higher Education. As a replacement to this caste system, all universities in Indonesia, both public and private, were to be assessed in terms of quality and efficiency by an independent accreditation body, the National Accreditation Board of Higher Education (Badan Akreditasi Nasional Perguruan Tinggi or BAN-PT). BAN-PT was established by the Minister of Education and Culture Decree No. 187/U/1994 of 1994.

After the New Order era, the country started to reform its national education system. One of its reform agenda goals was the extension of autonomy of Indonesian higher education institutions. To realise this objective, the government issued Government Regulation No. 61 of 1999 on the Public University as a Legal Entity, which stated that all public universities had the status of a state-owned legal entity (Badan Hukum Milik Negara or BHMN). ${ }^{59}$ The government then asked four leading public universities, namely, UI, UGM, Bandung Institute of Technology (ITB) and Bogor Institute of Agriculture (IPB), to become the pioneers of BHMN universities. ${ }^{60}$ As a BHMN, these four institutions were no longer regarded as part of the bureaucracy. They were no longer accountable to the Minister of Education, but they were directly responsible to community and were represented by a Board of Trustees. ${ }^{61}$ Aside from that, they were given autonomy to manage their own finances and as a consequence, no longer received financial assistance from the government as public universities traditionally did. To meet their financial needs, BHMN public universities were given greater access to organised activities that generated revenue. ${ }^{62}$ 
When the number of public universities switching their status to BHMN was increasing, the government passed Law No. 20 of 2003 on the National Education System, which stipulated that formal education providers in Indonesia, including those in higher education, should be formed into an education legal entity (Badan Hukum Pendidikan or BHP) ${ }^{63}$ In line with this, the government issued Law No. 9 of 2009 on the Education Legal Entity which provided a wider independence for organisers of formal education institutions, including those involved in higher education, to adopt a business-oriented management model. ${ }^{64}$ Even though this law aimed to improve the quality of higher education in Indonesia, it was protested because it required education providers to run their institutions in accordance with market mechanisms free from any protection by the government. Eventually, Law No. 9 of 2009 on the Education Legal Body was overruled by the Constitutional Court in $2010 .{ }^{65}$ The Constitutional Court deemed the law to be contrary to the spirit of the 1945 Constitution, which dictated that education was the responsibility of the state and should be freely accessible to all citizens. ${ }^{66}$

After that, the government passed Law No. 12 of 2012 on Higher Education. Now, the law further strengthens the position of private universities in Indonesia because it places private universities on the same level as public universities. ${ }^{67}$ The "same level" means that the government allocates state budget funds ${ }^{68}$ for both public and private universities. The budget for private universities is to be used for a professional lecturer allowance, professor honorary allowance, research and development, and grants for students attending higher education institutions. ${ }^{69}$

\section{THE ROLE OF INDONESIAN PRIVATE LAW SCHOOLS IN SOCIETY}

Before the beginning of the political reformation period in Indonesia in 1998, the role of the private sector in conducting legal education in the society was limited. Private law schools provided merely an educational alternative for those who could not enter a public law school. However, coinciding with the development of Indonesia as a nation, there was an increasing demand for legal scholars to work in governmental and private institutions. ${ }^{70}$ However, due to their limited capacities at the time, public law faculties were incapable of accommodating all prospective students. Given this situation, the private sector became key to creating additional space for these students.

In response to the large number of students that were not accepted into public law institutions, the number of students accepted to study law 
by at private institutions increased. At that time, the total number of private universities in Indonesia was estimated to be more than 3,000 institutions. ${ }^{71}$ Although not every private university had opened a school of law, the fact that establishing a school of law was not a particularly costly investment meant that there was a large number of total law schools in Indonesia. Unfortunately, many of these were private law schools that were established with inadequate financial support, poor facilities and a general lack of the human resources needed to provide a quality education. ${ }^{72}$

At that time, the limited number of spaces for law students at public universities necessitated the imposition of a strict selection process to screen student candidates. Nevertheless, the selection criteria were not based solely on the academic abilities of the candidates. Often, the political interests of the Indonesian government had a strong influence on the selection process. One such political policy restricted the quota for Indonesian citizens of Chinese descent who wished to enjoy education in public schools, including law schools, to 40 percent. ${ }^{73}$ Such discriminatory policies made private universities more popular than public ones in the eyes of Chinese-Indonesians.

Although some law schools within private universities such as the Islamic University of Indonesia (Universitas Islam Indonesia or UII), Atma Jaya Catholic University of Indonesia (UAJ), Trisakti University (Usakti), and Parahyangan Catholic University (Universitas Parahyangan or Unpar), provide a high-quality legal education in Indonesia, private universities bear a stereotype in the public mind as being of a decidedly lower quality in comparison with public universities. ${ }^{74}$ This view was strengthened as the government imposed a caste-like system of labelling private universities with the differing statuses of Equated, Recognised and Registered, with all the concomitant consequences on those schools. On the other hand, the government had never differentiated the status of public universities with respect to the quality of the education provided, despite the fact that many public universities, particularly those in the eastern part of Indonesia, in reality provided a lower quality education than some of the better private universities in the western region of the country.

Fortunately, this caste-like system was changed in the 1990s. During this period, the government implemented an accreditation system for private law schools that was more transparent and non-discriminatory. The implementation of this process occurred almost simultaneously with the start of the reformation era in Indonesia in 1998. After 30 years under the authoritarian New Order regime, Indonesia reformed various sectors of its social institutions, including higher education. The reform carried out in the field of education gave more 
autonomy to the state in managing academic activities and resulted in more equitable treatment between public and private universities. ${ }^{75}$

Before the reformation of 1998, most graduates of public law schools preferred to work for the government, while most graduates of private universities, particularly those of Chinese descent, worked in the private sector. ${ }^{76}$ Despite the fact that there was no formal prohibition in Indonesia on private university graduates applying to be civil servants (Pegawai Negeri Sipil or PNS), the recruitment process at the time was not transparent and was laden with corruption, collusion and nepotism, ${ }^{77}$ making the majority of private school law graduates reluctant to work in the public sector.

However, since 1998, there have been major reforms of state institutions in the areas of the electoral process, workings of parliament, budgeting and finance, development of a rule of law, judiciary and military. ${ }^{78}$ Aside from the eradication of the collusion, corruption and nepotism that were entrenched in all state institutions, another element of the reform was the establishment of many new state institutions, such as the Constitutional Court, the Corruption Eradication Commission, the Judicial Commission and the Ombudsman of the Republic of Indonesia. ${ }^{79}$ The establishment of new state institutions had certainly been accompanied by the need for more human resources to run them. In contrast to the pre-reformation era, at this time the recruitment processes of state institutions, whether they were new or existing institutions, were more transparent, less corrupt, and freer of collusion and nepotism practices. This offers new opportunities for all law graduates, whether they are from public or private schools, to take up positions in government institutions.

Since the reformation era, the role of private law schools in Indonesian society has been altered. They no longer merely act as an alternative educational institution to public law schools. In fact, the capacity of private university graduates is proven to be equal to that of their public university counterparts. According to the BAN-PT, the accreditation of universities and study programmes takes place every 5 years; there are only 58 law schools in Indonesia that are accredited with an "A" rating by the BANPT based on 7 criteria: (1) vision, mission, targets and goals, and strategic planning; (2) management, leadership and quality; (3) students and graduates; (4) human resources; (5) curriculum, learning and academic setting; (6) funding, facility, and information technology; and (7) research, community service and collaboration. Surprisingly, 34 of these law schools are private institutions. On the other hand, only 24 of the 33 public law schools in Indonesia have an "A" rating. ${ }^{80}$

Furthermore, these private law schools also produce graduates who are able to play important roles in both the public and private sectors at the 
local and national levels. In 2014, Tempo magazine ${ }^{81}$ conducted a survey with respondents from the 55 largest Indonesian enterprises according to the 2013 issue of Fortune Indonesia magazine..$^{82}$ The respondents were asked about the best law school graduates in Indonesia who they would like to recruit. The result placed some private law schools (UAJ, Usakti and Christian University of Indonesia) in the top ten list with other leading public law schools, such as UI, UGM, Unpad, Undip, Unair and USU. In the public sector, it has recently become more common to see many public law school graduates occupying important positions in state institutions. For instance, Dr. Artidjo Alkostar, a Justice of the Indonesian Supreme Court, and Dr. Mahfud M. D., former Chief Justice of the Indonesian Constitutional Court, are both alumni of UII Law School, a leading private university located in Yogyakarta ${ }^{83}$ Another example is Marzuki Darusman, an Unpar Law School graduate, who held the position of Attorney General from 1999 to $2001 .^{84}$

\section{CONCLUSION}

The participation of private universities in the provision of legal education in Indonesia has existed as long as the country itself. Along the journey to statehood, it is undeniable that private law schools have contributed a great deal to Indonesian society. Initially, they were the victims of discriminatory treatment by the government and were only considered an alternative educational institution for individuals who were not accepted at the public law schools. However, after the reform era, private law schools, especially those of exceptional quality, have managed to prove that their worth is equal to that of the public universities if they are given equal opportunity and access to state assistance. However, this should not make private universities complacent, as the fact remains that many private institutions are still inadequate in terms of quality and facilities.

\section{NOTES}

* V. Selvie Sinaga is an Associate Professor of Law at Faculty of Law, Atma Jaya Catholic University of Indonesia (AJCUI), Indonesia. She obtained LLB from Gadjah Mada University, Indonesia, LLM from Monash University, Australia, and PhD in Law from University of Wollongong, Australia. She won prestigious Australian Development Scholarship from the Australian government for pursuing her master and doctoral studies in 2002 and 2008. She teaches international law, intellectual property law, English law and treaty law. Her research interests are international and socio legal aspects of 
intellectual property law, law and development, and legal education in Indonesia. Since the outset of her academic career, she has actively presented and published her research findings at national and international level. Apart from her academic career, she is also a practicing lawyer, specialised in intellectual property and public interest cases.

1 Currently, most public universities in Indonesia receive approximately two-thirds of their budget from the state. See Purwadi, A., "Impact of the economy crisis on higher education in Indonesia," in Impact of the economy crisis on higher education in East Asia, ed. Varghese, N. V., 61-75 (Paris: IIEP/ Unesco) and Welch, A., "Blurred vision: Public and private higher education in Indonesia," Higher Education Vol. 54 (2007), 665-687. Further discussion on this subject will be presented in the topic "Governance of Private Higher Education Institution in Indonesia."

2 For example, in terms of conducting research, in the last five years, the Directorate General of Higher Education (DGHE) Indonesia created two categories of research grants, namely, centralised and decentralised research grants. The centralised research grants are open to all academic staff, and the selection is conducted nationally. The decentralised research grants are open to academic staff only in certain universities (public universities) or under coordination of a private university coordinator (Kopertis). It can be seen that the chances of the public universities are doubled and more specialised. Here, the support from the government for public universities can be clearly seen. See, Wiryawan, K. G., "The current status of science journals in Indonesia," Science Editing Vol. 1, No. 2: 71-75, https:// doi.org/10.6087/kcse.2014.1.71 (accessed 22 June 2017).

3 Wignjosoebroto, S., "Perkembangan hukum nasional dan pendidikan hukum di Indonesia pada era pascakolonial" (Development of the national law and legal education in Indonesia in the post-colonial era), 1992, http://huma.or.id/wp-content/ uploads/2006/08/Perkembangan-Hukum-Nasional-Pendidikan-Hukum-Di-IndonesiaPada-Era-Pascakolonial_Soetandyo.pdf (accessed 2 February 2016).

4 Universitas Gadjah Mada. Profil (Profile), http://law.ugm.ac.id/?page_id=177 (accessed 3 February 2016).

5 Hukumonline, "Bermula dari rechtshogeschool (Starting from rechtshogeschool)," 20 May 2013, http://www.hukumonline.com/berita/baca/lt51a71729d07f5/bermula-dariirechtshogeschool-i (accessed 5 February 2016)

6 Universitas Islam Indonesia, "Sejarah singkat (Short history)," http://www.uii.ac.id/ content/view/17/33/?lang=id (accessed 5 February 2016).

7 Universitas Krisnadwipayana, "Sejarah singkat UNKRIS" (Short history of UNKRIS), http://unkris.ac.id/index.php?page=tentang\&ket=sejarah (accessed 5 February 2016).

8 Direktorat Jendral Pendidikan Tinggi, "Hasil pencarian program studi (Searching results of study program)," http://forlap.dikti.go.id/prodi/search/360 (accessed 6 February 2016).

9 Fakultas Hukum Universitas Indonesia, "Sejarah dan perkembangan" (History and development), http://law.ui.ac.id/v2/profil/sejarah-dan-perkembangan (accessed 15 January 2016).

10 Ibid.

11 Landraad was a special court to hear and adjudicate all civil and criminal cases involving indigenous and foreign groups in the East Indies. See, Massier, A., The voice of the law in transition: Indonesian jurists and their languages (1915-2000) (Leiden: KITLV, 2008). 
12

13

14

15

16 Disiplin Ilmu Hukum or KDIH), was an organisation consisting of Indonesian public law schools. Prior to the dissolution of this organisation in 2002, the Indonesian government assigned it the duty of developing a national curriculum of higher education in law in Indonesia. Ibid, 13.

17 Wignjosoebroto, Perkembangan hukum nasional, 10.

18 Juwana, Legal education reform in Indonesia, 4.

19 Ibid, 4.

20 Komisi Hukum Nasional (National Legal Commission), "Menuju paradigma baru pembangunan hukum nasional" (Towards a new national legal development paradigm), 2005, http://www.komisihukum.go.id/article_opinion.php?mode=detil\&id=113 (accessed 30 January 2016).

$21 \quad$ National Education System Act (2013) s. 38 (3).

22 This provision was reaffirmed in Government Regulation on Management and Implementation of Education, 2010, Indonesia, s 17 (4 and 4a) and 97.

23 Pancasila is the five principles of Indonesian state philosophy. For a detailed explanation, see Encyclopedia Britannica, "Pancasila: Indonesian political philosophy," http://www.britannica.com/topic/Pancasila (accessed 20 January 2016).

Higher Education Act, 2012, Indonesia, s. 35 (3).

KKNI is a framework for a hierarchy of competence that can match, equalise and integrate education and job training, as well as work experience, in order to give recognition to work competence in accordance with the job structure of various sectors. KKNI consists of nine levels of qualifications, starting with graduates of elementary school at level one to those with doctoral degrees at level nine. See Presidential Regulation on Indonesian National Qualification Framework, 2012, Indonesia, ss. 1 (1) and (5).

Ibid.

Wignjosoebroto, Perkembangan hukum nasional, 1.

Some of the research on private higher education are: Lejeune, M., "The challenges of catholic universities in Africa: The role of ACUHIAM," in Private higher education: A global revolution, eds. Altbach, P. G. and Levy, D. C., 55-58 (Rotterdam: Sense Publishers); Levy, D. C., "Legitimacy in central and eastern European private higher education," in Private higher education: A global revolution, eds. Altbach, P. G. and Levy, D. C., 171-174 (Rotterdam: Sense Publishers); Cummings, W. K. "Private education in eastern Asia," in The challenge of eastern Asia education: Implications for America, eds. Cummings, W. K. and Altbach, P. G., 135-152 (Albany: State University of New York Press); Gonzales, A., "Private higher education in the Philippines: Private domination in developing countries," in Private prometheus: Private higher education development in the 21st Century, ed. Altbach, P. G., 101-112 (Westport, CT: Greenwood); Altbach, P. G., "The Past and future of Asian universities: Twenty-first century challenges," in Asian universities: Historical perspectives and contemporary challenges, eds. Altbach, P. G. and Umakoshi, T., 13-32 (Baltimore \& London: The Johns Hopkins University Press); Umakoshi, T., "Private higher education in Asia: 
Transition and development," in Asian universities: historical perspectives and contemporary challenges, eds. Altbach, P. G. and Umakoshi, T., 33-52 (Baltimore \& London: The Johns Hopkins University Press).

29 Altbach, P. G., "The Private higher education revolution: An introduction," in Private higher education: A global revolution, eds. Altbach, P. G. and Levy, D. C., 1-12 (Rotterdam: Sense Publishers). In the 2017, in The Times Higher Education Ranking for Law in the US, there are six private law schools (Stanford, Harvard, Yale, Duke, Cornell and Northwestern) included in the top ten list. See Times Higher Education: World university ranking 2016-17, https://www.timeshighereducation.com/world-university-rankings/2017/worldranking\#!/page/0/length/25/locations/US/subjects/3093/sort_by/rank/sort_order/asc/ cols/stats (accessed 4 October 2017).

31 Examples of these high-quality private universities are Waseda and Keio in Japan, De La Salle and the Ateneo de Manila in the Philippines, Yonsei in South Korea and Atma Jaya in Indonesia. Altbach, The past and future of Asian universities: Twenty-first century challenges, 24.

32 India is an exception in terms of public funding since Indian private universities are affiliated with public universities and receive a significant part of their funding from the government. See Altbach, The private higher education revolution: An introduction, 2-3.

33 Besides the Ministry of Research, Technology and Higher Education, the Ministry of Religious Affairs is also given authority to manage all public and private higher education institutions specialised in Islamic studies. In these Islamic higher education institutions, there is legal education being offered under a Syariah (Islamic Law) Department. For a detailed discussion of Islamic legal education in Indonesia, see Parsons, J. and Makruf, J., "Islamic legal education in Indonesia: Tradition in transition," in Legal education in Asia: Globalization, change and contexts, eds. Steele, S. and Taylor, K., 298-325 (London: Routledge).

34 Hermawan, B., "Ini nama-nama menteri Kabinet Kerja Jokowi-JK (These are names of minister in the Jokowi-JK Working Cabinet)," Republika, 26 October 2014, http://www.republika.co.id/berita/nasional/politik/14/10/26/ne1 sau-ini-namanamamenteri-kabinet-kerja-jokowijk (accessed 26 January 2016).

35 Fitri, "Seandainya kopertis tidak ada lagi" (If Kopertis does not exist anymore), Koordinator Perguruan Tinggi Swasta, 28 April 2011, http://www.kopertis12. or.id/2011/04/28/seandainya-kopertis-tak-ada-lagi.html (accessed 25 January 2016).

36 Kopertis Region I covers North Sumatra and the Special Region of Aceh; Kopertis Region II covers South Sumatra, Lampung and Bengkulu; Kopertis Region III covers Jakarta region; Kopertis Region IV covers West Java and Banten; Kopertis Region V covers Special Region of Yogyakarta; Kopertis Region VI covers Central Java; Kopertis Region VII covers East Java; Kopertis Region VIII covers Bali and East Nusa Tenggara; Kopertis Region IX covers South, Central, North, and Southeast Sulawesi, Kopertis Region X covers West Sumatra, Riau and Jambi; Kopertis Region XI covers South, West, East, and Central Kalimantan; and Kopertis Region XII covers Maluku and Papua. See Kopertis Satu, "Sejarah” (History), 8 March 2012, http://www.kopertis1. or.id/hal-sejarah.html (accessed 10 February 2016). 
37 Simamora, A. P., "Liberalisasi pendidikan dalam kerangka GATS: Kajian hukum terhadap pendirian perguruan tinggi asing di Indonesia" (Liberalisation of education in the framework of GATS: Legal study on the establishment of foreign university in Indonesia) (Master of Law diss., Universitas Sumatera Utara-Indonesia, 2013). Ibid, 37. See also Higher Education Act, 1961, Indonesia, s 25.

If the founder of the private university does not report the establishment of that particular university within the stipulated time, the founder was deemed to be conducting a criminal offence. See Higher Education Act, 1961, Indonesia, s 26.

Higher Education Act, 1961, Indonesia, s 27 (3).

Ibid, s 27 (4).

Ibid, s 27.

Ibid, s 24 (1).

Ibid, s 27 (1).

Ibid, s 28.

Ibid, s 30 .

Kopertis Satu, Sejarah.

Ibid.

Fitri, Seandainya kopertis tidak ada lagi.

Simamora, Liberalisasi pendidikan: 38.

Sulistiyono, S. T., "Higher education reform in Indonesia at crossroad," paper presented at the Graduate School of Education and Human Development, Nagoya University, Japan, Nagoya, 26 July 2007, 6.

Buchori, M. and Malik, A., "The evolution of higher education in Indonesia" in Asian universities: Historical perspectives and contemporary challenges, eds. Albatch, P. and Umakoshi, T. (Baltimore: The Johns Hopskin University Press, 2004), 261.

Sulistiyono, Higher education reform in Indonesia.

The government still issued several discriminatory regulations regarding private universities, which include the Minister of Education and Culture Decree No. 20/U/1986 of 1986 on State Examination for Private University Students and the Minister of Education and Culture Decree No. 198 /U/1987 of 1987 on Independent Examination Conduct of "Recognised" Private Universities. See Kopertis Satu, Sejarah.

55 In the Old Order and New Order eras (1945-1998), the Indonesian government actually did not grant broad autonomy for the running of higher education in public universities, either. At that time, the Indonesian government still positioned public universities as part of the government bureaucracy, including the way in which they managed financial arrangements, salaries and promotions of their staff. This structure enabled the government to force its political interest on higher education institutions, which were supposed to be independent. See Sulistiyono, Higher education reform in Indonesia, 8. Simamora, Liberalisasi pendidikan, 39.

Government Regulation on Higher Education, 1990, Indonesia, s 115. Ibid, s 121.

Government Regulation on Establishment of Public Higher Education as Legal Entity, 1999, Indonesia, s 2.

Wicaksono, T. Y. and Friawan, D. "Recent developments in higher education in Indonesia: issues and challenges," in Financing higher education and economic development in 
East Asia, eds. Armstrong, S. and Chapman, B. (Canberra, ANU E-Press, 2011), 159188.

61 Ibid.

62 Sulistiyono, Higher education reform in Indonesia, 9.

63 National Education System Act, 2003, Indonesia, S 53 (1).

64 Heyward, M. and Sopantini, "Indonesia: The challenges of quality and equity in education," in Education around the world: Education in south-east Asia, ed. Symaco, L. P. (London: Bloomsbury, 2013), 71-94.

Hukumonline, "MK batalkan UU Badan Hukum Pendidikan (Constitutional court revokes act on education legal entity)," 31 March 2010, http:/www.hukumonline.com/ berita/baca/lt4bb37a39de6cc/mk-batalkan-uu-badan-hukum-pendidikan (accessed 3 March 2016). Heyward and Sopantini, The challenges of quality and equity in education, 85-86.

Wijaya, A., "Jangan ada lagi kesenjangan PTN dan PTS (No more gap between state and private universities)," Warta Perundang-undangan Vol. 22, No. 39 (2012): 11-13. Higher education act, 2012, Indonesia, s 83 (1). general, see ibid; Buchori and Malik, The evolution of higher education in Indonesia, 261-262.

73 Sections 7, 8 and 9 of the Presidential Instruction No. 37 of 1967 on the Government's Main Policy on Chinese Descendants. See, Lindsey, T. (2005) "Reconstituting the ethnic Chinese in post-Soeharto Indonesia: Law, racial discrimination, and reform" in Chinese Indonesians: Remembering, distorting, forgetting, ed. Lindsey, T. and Pausacker, H. (Singapore: ISEAS: 2005), 56.

In the New Order era, the number of ethnic Chinese descendants accepted to the state universities, government bodies and military was limited. See, Lindsey, Reconstituting the ethnic Chinese: 56; Frost, N., Indonesia: The background, the issues, the people (Dorset: Oxfam, 2002), 43.

77 Arisman, "Penataan sistem penerimaan Pegawai Negeri Sipil (Management of civil servant recruitment system)," Kementerian Hukum dan Hak Asasi Manusia, 21 February 2014, http://jakarta.kemenkumham.go.id/download/karya-ilmiah/sdm/61penataan-sistem-penerimaan-pegawai-negeri-sipil/file (acessed 18 February 2016). Harris, D. and Foresti, M., Indonesia's progress on governance: State cohesion and strategic institutional reform (London: Overseas Development Institute, 2011 ), 9. Ibid, 10.

Badan Akreditasi Nasional Perguruan Tinggi, "Daftar hasil akreditasi program studi (List of program accreditation result)," https://banpt.or.id/direktori/prodi/pencarian_ prodi (accessed 17 June 2017).

81 For more than 10 years, Tempo, a leading Indonesian national magazine, has conducted an annual survey to assess the ranking of Indonesian public and private universities with regard to several study programs, including law, in various categories. Although 
this is an unofficial survey from a non-governmental source, it is popular, and the public has used it as a reference point in students' determination regarding the colleges or universities that they wish to attend.

82 Mulyani, A. et al., Panduan memilih perguruan tinggi 2014 (Guidance to select university 2014), eds. Februana, N. and Priyambodo, D. (Jakarta: Pusat Data dan Analisa Tempo), 79-102.

83 Putra, E. P., "Ini rahasia alumni Fakultas Hukum UII banyak duduk di lembaga negara (This is the secret of many alumni of Islamic University of Indonesia's Law School hold position in state agencies)," Republika, 9 August 2015.

84 Biro Kemahasiswaan dan Alumni Universitas Katolik Parahyangan, "Daftar alumnus Unpar (Alumni of Unpar list),” http://ika.unpar.or.id (accessed 25 February 2016).

\section{REFERENCES}

Altbach, P. G. 2004. The past and future of Asian universities: Twenty-first century challenges. In Asian universities: Historical perspectives and contemporary challenges, eds. Altbach, P.G. and Umakoshi, T., 13-32. Baltimore and London: Johns Hopkins University Press.

Altbach, P. G. 2005. The private higher education revolution: An introduction. In Private higher education: A global revolution, eds. Altbach, P. G. and Levy, D. C., 1-12. Rotterdam: Sense Publishers.

Arisman. 2014. Penataan sistem penerimaan pegawai negeri sipil (Management of civil servant recruitment system). Kementerian Hukum dan Hak Asasi Manusia, 21 February. http://jakarta.kemenkumham.go.id/download/karya-ilmiah/sdm/61penataan-sistem-penerimaan-pegawai-negeri-sipil/file (accessed 18 February 2016).

Badan Akreditasi Nasional Perguruan Tinggi. Daftar hasil akreditasi program studi (List of study program accreditation result). https://banpt.or.id/direktori/prodi/pencarian prodi (accessed 17 June 2017).

Biro Kemahasiswaan dan Alumni Universitas Katolik Parahyangan. Daftar alumnus Unpar (Alumni of Unpar list). http://ika.unpar.or.id (accessed 25 February 2016).

Buchori, M. and Malik, A. 2004. The evolution of higher education in Indonesia. In Asian universities: Historical perspectives and contemporary challenges, eds. Albatch, $\mathrm{P}$. G. and Umakoshi, T., 249-277. Baltimore: Johns Hopskin University Press.

Cummings, W. K. 1997. Private education in eastern Asia. In The challenge of eastern Asia education: Implications for America, eds. Cummings, W. K. and Altbach, P. G., 135-152. Albany: State University of New York Press.

Direktorat Jendral Pendidikan Tinggi. 2015. Hasil pencarian program studi (Searching results of study program). http://forlap.dikti.go.id/prodi/search/360 (accessed 6 February 2016).

Encyclopedia Britannica. n. d. Pancasila: Indonesian political philosophy. http://www. britannica.com/topic/Pancasila (accessed 20 January 2016).

Fakultas Hukum Universitas Indonesia. Sejarah dan perkembangan (History and development). http://law.ui.ac.id/v2/profil/sejarah-dan-perkembangan (accessed 15 January 2016). 
Fitri. 2011. Seandainya Kopertis tidak ada lagi (If Kopertis does not exist anymore), 4 November. http://www.kopertis12.or.id/2011/04/28/seandainya-kopertis-tak-adalagi.html (accessed by 25 January 2016).

Gonzalez, A. 1999. Private higher education in the Philippines: Private domination in developing countries. In Private promotheus: Private higher education development in the 21st century, ed. Altbach, P. G., 101-112. Westport, CT: Greenwood.

Juwana, H. 2006. Legal education reform in Indonesia. Asian Journal of Comparative Law 1 (1), https://doi.org/10.2202/1932-0205.1016.

Harris, D. and Foresti, M. 2011. Indonesia's progress on governance: State cohesion and strategic institutional reform. London: Overseas Development Institute.

Hermawan, B. 2014. Ini nama-nama menteri Kabinet Kerja Jokowi-JK (These are the names of minister in the Jokowi-JK Working Cabinet). Republika, 26 October. http://www.republika.co.id/berita/nasional/politik/14/10/26/ne1 sau-ini-namanamamenteri-kabinet-kerja-jokowijk (accessed 26 January 2016).

Heyward, M. and Sopantini. 2013. Indonesia: The challenges of quality and equity in education. In Education around the world: Education in South-East Asia, ed. Symaco, L. P., 71-94. London: Bloomsbury.

Hukumonline. 2013. Bermula dari rechtshogeschool (Starting from rechtshogeschool), 20 May. http://www.hukumonline.com/berita/baca/lt51a71729d07f5/bermula-dariirechtshogeschool-i (accessed 5 February 2016).

Hukumonline. 2010. MK batalkan UU Badan Hukum Pendidikan (Constitutional Court revokes act on education legal entity). 31 March. http://www.hukumonline.com/ berita/baca/lt4bb37a39de6cc/mk-batalkan-uu-badan-hukum-pendidikan (accessed 3 March 2016).

Komisi Hukum Nasional (National Legal Commission). 2005. Menuju paradigma baru pembangunan hukum nasional (Towards a new national legal development paradigm). http://www.komisihukum.go.id/article_opinion.php?mode=detil\&id=113>. (accessed 30 January 2016).

Kopertis Satu. 2012. Sejarah (History). 8 March. http://www.kopertis1.or.id/hal-sejarah. html (accessed 10 February 2016).

Lejeune, M. 2005.The challenges of catholic universities in Africa: The role of ACUHIAM. In Private higher education: A global revolution, eds. Altbach, P. G. and Levy, D. C., 55-58. Rotterdam: Sense Publishers.

Levy, D. C. 2005. Legitimacy in central and eastern European private higher education. In Private higher education: A global revolution, eds. Altbach, P. G. and Levy, D. C., 171-174. Rotterdam: Sense Publishers.

Lindsey, T. 2005. Reconstituting the ethnic chinese in post-Soeharto Indonesia: Law, racial discrimination, and reform. In Chinese Indonesians: Remembering, distorting, forgetting, eds. Lindsey, T. and Pausacker, H., 15-41. Singapore: ISEAS, https:// doi.org/10.1355/9789812305442-007.

Massier, A. 2008. The voice of the law in transition: Indonesian jurists and their languages (1915-2000). Leiden: KITLV, https://doi.org/10.1163/9789004253964.

Mulyani, A. et al. 2014. Panduan memilih perguruan tinggi 2014 (Guidance to select university 2014), eds. Febriana, N. and Priyambodo, D. 79-102. Jakarta: Pusat Data dan Analisa Tempo. 
Parsons, J. and Makruf, J. 2010. Islamic legal education in Indonesia: Tradition in transition. In Legal education in Asia: Globalization, change and contexts, eds. Steele, S. and Taylor, K., 298-325. London: Routledge.

Purwadi, A. 2001. Impact of the economy crisis on higher education in Indonesia. In Impact of the economy crisis on higher education in East Asia, ed. Varghese, N. V., 61-75. Paris: IIEP/ Unesco.

Putra, E. P. 2015. Ini rahasia alumni Fakultas Hukum UII banyak duduk di lembaga negara (This is the secret of many alumni of Islamic University of Indonesia's Law School hold position in state institutions). Republika, 9 August.

Simamora, A. P. 2013. Liberalisasi pendidikan dalam kerangka GATS: Kajian hukum terhadap pendirian perguruan tinggi asing di Indonesia (Liberalisation of education in the framework of GATS: Legal study on the establishment of foreign university in Indonesia). LLM diss., Universitas Sumatera Utara-Indonesia.

Sulistiyono, S. T. 2007. Higher education reform in Indonesia at crossroad. Paper presented at the Graduate School of Education and Human Development, Nagoya University, 26 July, Nagoya.

Times Higher Education: World university ranking 2016-17. https://www. timeshighereducation.com/world-university-rankings/2017/world-ranking\#!/ page/0/length/25/locations/US/subjects/3093/sort_by/rank/sort_order/asc/cols/ stats (accessed 4 October 2017).

Umakoshi, T. 2004. Private higher education in Asia: Transition and development. In Asian universities: Historical perspectives and contemporary challenges, eds. Altbach, P. G. and Umakoshi, T., 33-52. Baltimore and London: The Johns Hopkins University Press.

Universitas Gadjah Mada. n. d. Profil (Profile). http://law.ugm.ac.id/?page_id=177 (accessed 3 February 2016).

Universitas Islam Indonesia. n. d. Sejarah singkat (Short history). http://www.uii.ac.id/ content/view/17/33/?lang=id (accessed 5 February 2016).

Universitas Krisnadwipayana. n. d. Sejarah singkat UNKRIS (Short history of UNKRIS). http://unkris.ac.id/index.php?page=tentang\&ket=sejarah (accessed 5 February 2016).

Welch, A. 2007. Blurred vision: public and private higher education in Indonesia. Higher Education 54: 665-687, https://doi.org/10.1007/s10734-006-9017-5.

Wicaksono, T. Y. and Friawan, D. 2011. Recent developments in higher education in Indonesia: Issues and challenges. In Financing higher education and economic development in East Asia, eds. Armstrong, S. and Chapman, B., 159-188. Canberra: ANU E-Press.

Wijaya, A. 2012. Jangan ada lagi kesenjangan PTN dan PTS (No more gap between state and private Universities). Warta Perundang-undangan 22 (39): 11-13.

Wignjosoebroto, S. 1992. Perkembangan hukum nasional dan pendidikan hukum di Indonesia pada era pascakolonial (Development of the national law and legal dducation in Indonesia in the post-colonial era). http://huma.or.id/wp-content/uploads/2006/08/ Perkembangan-Hukum-Nasional-Pendidikan-Hukum-Di-Indonesia-Pada-EraPascakolonial_Soetandyo.pdf (accessed 2 February 2016).

Wiryawan, K. G. 2014. The current status of science journals in Indonesia. Science Editing 1 (2): 71-75, https://doi.org/10.6087/kcse.2014.1.71. 